\title{
Science Teachers' Perception About Laboratory Activity on Mixture Separation Topics
}

\author{
R Meidayanti ${ }^{{ }^{*}}{ }^{*}$ N Fadiawati ${ }^{1}$, and C Diawati ${ }^{1}$ \\ ${ }^{1}$ Universitas Negeri Lampung, INDONESIA
}

Received 3 August 2019 - Revised 2 October 2019 - Accepted 28 October 2019

\begin{abstract}
This study aimed to explore seventh grade science teachers' perception about laboratory activity on mixture separation topics and match them with available evidence from learning document. The design of this research is survey research. The sample comprised 10 seventh grade science teachers, purposive sampled from seventeen teachers. Questionnaires and interview guidelines were used to collect data. The results shown that while teachers' perceptions on mixture separation topics in science classrooms is inadequate. It caused, there was a mismatch between teachers' perceptions, learning document, and what was taking place in the science classroom. The study may inform teachers' performance in teaching mixture separation topics in science. It is recommended that teacher on learning should be used practice worksheet and assessment of laboratory activity, as most of the teachers do not record marks regularly for laboratory activity. Futhermore, laboratory activity which prepared by the teacher should arranged in lesson plan and practice schedules.
\end{abstract}

Keywords: laboratory activity, mixture separation, perception, science teacher

\section{INTRODUCTION}

Laboratory activity was an important part in the nature of science [1]. Laboratory activities have long had a distinctive and central role in the science curriculum and science educators have suggested that many benefits accrue from engaging students in science laboratory activities [2-9]. Laboratory activity have been used in many natural science disciplines to teach students of many age spans in very different cultural and classroom contexts[10].

This activity could build up students motivation and achievement in natural of science learning, skills developing, based experimenting, practice skill developing, and has a role as a learning model in science metodh application [3]. Furthermore, hands-on laboratory activity was also potential to provide higher order thinking skills [11]. Laboratory activity appeal as a way to learn with understanding and, at the same time, engage in a process of constructing knowledge by doing science. Learning is possible in the laboratory if students are given opportunities to manipulate equipment and materials in order to be able to construct their knowledge of phenomena and related scientific concepts [4].

Laboratory activity are also called practical work [12]. Practical work is an integral part of science education and various science educationists have evaluated its purposes [13]. Practical work can be referred to as active learning with the responsibility of organizing what is to be learned [12]. When the teachers' focus on the practical lessons was predominantly one of developing scientific knowledge rather than developing scientific enquiry and that practical work was generally effective at getting pupils to do what was intended with physical objects rather than use scientific ideas and reflect on the data. They note that there was little evidence of a cognitive challenge in linking observables to ideas, and that practical tasks rarely incorporated explicit strategies to help pupils make

(C) 2019 by the authors; licensee PGSD UMP. This article is an open access article distributed under the terms and conditions of the Creative Commons Attribution License

(http://creativecommons.org/licenses/by/4.0/).

renimeidayanti@gmail.com (*Correspondence) 
these links [14].

Over the years, many have argued that science cannot be meaningful to students without worthwhile practical experiences in the school laboratory. Some laboratory activities have been designed and conducted to engage students individually, while others have sought to engage students in small groups and in large-group demonstrationsettings[10].Many research studies have been conducted to investigate the educational effectiveness of laboratory activity in science education in facilitating the attainment of the cognitive, affective, and practical goals. These studies have been critically and extensively reviewed in the literature [2][5-6][15-16].

Teachers' perceptions regarding laboratory activity in the teaching of Natural Science are important as such perceptions determine their actions in science classrooms [17]. One study result shows that science teacher's view laboratory activity as indispensable for improving the quality of science learning. Laboratory activity are one of the tools for visualization, application, observation and experimentation related to the concepts of science studied [18]. Some teachers complain about the lack of skills to use laboratory equipment, whilst others claim that they lack adequate time for practical work. These complaints do not remove the role practical work plays in learningScience [19].

In this study, a more complete investigation was undertaken to explore science teacher's perceptions regarding mixture separation laboratory activity. When mixture separation is one of the subjects of natural science at the level junior high school in Indonesia.

\section{MATERIAL AND METHODS}

\section{Methods}

The design of this research is survey research. The major purpose of surveys is to describe the characteristics of a population [20]. This research was a descriptive study to get the description of science teacher perception about mixture separation laboratory activity. It follows a series of other studies conducted in Lampung, Indonesia. There were a total of seventeen science teachers who participated in the study. Ten were purposively selected based on their experiences which ranged between 5 and 10 years.

\section{Instrument}

The researcher used two instruments that is questionnaire and interview guidelines. The questionnaire in this study consisted of four closed-ended questions.

\section{Procedures}

the researcher gathered additional information from interview guidelines in order to corroborate teachers' responses to the questionnaire. Interview guidelines are structured semistructured interviews. Semistructured interviews are a series of questions designed to separate specific answers from respondents. Often they are used to obtain comparable and contrasted information that can be later [20]. The researchers were asked to answer the interview questions and their answers were written down on a piece of paper. After that, all statements were correctly recorded. The researcher examined all the learning materials for the components of the effectiveness of the work schedule, reflecting laboratory effectiveness plans, practice worksheets, and assessment records for practical work.

\section{Data Analysis}

The results of the questionnaires were analysed using the percentages of participants that 'agreed or disagreed' in eaof the four questions. The responses were sorted out per question showing correct choice. The percentage of acceptable choice from teachers was computed by taking correct choices of each question over the total number of teachers.

$$
\text { Acceptable } \%=\frac{\text { correctchoices }}{\text { totalpossiblechoices }} \times 100 \%
$$

Next interpret the percentage of the questionnaire as a whole by using Arikunto's interpretation [21] in Table 1. 
Table 1 Arikunto's interpretation

\begin{tabular}{cl}
\hline Percentage & \multicolumn{1}{c}{ Criteria } \\
\hline $80,1 \%-100 \%$ & Very High \\
\hline $60,1 \%-80 \%$ & High \\
\hline $40,1 \%-60 \%$ & Moderat \\
\hline $20,1 \%-40 \%$ & Low \\
\hline $0,0 \%-20 \%$ & Very Low \\
\hline
\end{tabular}

\section{RESULTS AND DISCUSSION}

\section{Science Teachers' Perceptions Regarding Mixture Separation Laboratory Activity}

Table 1 showed that the results data in Science teacher's perceptions regarding mixture separation laboratory activity discussed in four interview questions.

Table 1. Percentage answer from questions regarding mixture separation laboratory activity

\begin{tabular}{|c|c|c|c|c|c|c|c|c|}
\hline \multirow{2}{*}{ Respondent } & \multicolumn{2}{|c|}{$Q_{1}$} & \multicolumn{2}{|c|}{$\mathrm{Q}_{2}$} & \multicolumn{2}{|c|}{$\mathrm{Q}_{3}$} & \multicolumn{2}{|c|}{$\mathrm{Q}_{4}$} \\
\hline & Yes & No & Yes & No & Yes & No & Yes & No \\
\hline 1 & & $\sqrt{ }$ & $\sqrt{ }$ & & $\sqrt{ }$ & & $\sqrt{ }$ & \\
\hline 2 & $\sqrt{ }$ & & $\sqrt{ }$ & & & $\sqrt{ }$ & $\sqrt{ }$ & \\
\hline 3 & $\sqrt{ }$ & & & $\sqrt{ }$ & & $\sqrt{ }$ & & $\sqrt{ }$ \\
\hline 4 & & $\sqrt{ }$ & $\sqrt{ }$ & & & $\sqrt{ }$ & $\sqrt{ }$ & \\
\hline 5 & $\sqrt{ }$ & & & $\sqrt{ }$ & & $\sqrt{ }$ & & $\sqrt{ }$ \\
\hline 6 & $\sqrt{ }$ & & & $\sqrt{ }$ & $\sqrt{ }$ & & & $\sqrt{ }$ \\
\hline 7 & $\sqrt{ }$ & & $\sqrt{ }$ & & $\sqrt{ }$ & & $\sqrt{ }$ & \\
\hline 8 & $\sqrt{ }$ & & & $\sqrt{ }$ & & $\sqrt{ }$ & & $\sqrt{ }$ \\
\hline 9 & $\sqrt{ }$ & & & $\sqrt{ }$ & $\sqrt{ }$ & & & $\sqrt{ }$ \\
\hline 10 & $\sqrt{ }$ & & & $\sqrt{ }$ & & $\sqrt{ }$ & $\sqrt{ }$ & \\
\hline Acceptable \% & $80 \%$ & $20 \%$ & $40 \%$ & $60 \%$ & $40 \%$ & $60 \%$ & $50 \%$ & $50 \%$ \\
\hline Criteria & High & Low & Low & Moderat & Moderat & Moderat & Moderat & Moderat \\
\hline
\end{tabular}

$Q_{1}$ Do you often hold laboratory activities in learning?

As many as $80 \%$ stated that they often carry out laboratory activities in one year $>10$ times carrying out laboratory activities but the results of the confirmation with students of the teachers only carried out laboratory activities 2 or 3 in one school year. While $20 \%$ say honestly that they rarely carry out laboratory activities.

\section{$Q_{2}$ Do you design a mixture separation lesson plan accompanied by laboratory activities}

$40 \%$ stated that the lesson plan mixture separation is accompanied by laboratory activities, another case as much as $60 \%$ is not accompanied by laboratory activities because according to them it is impossible to involve students in practical work without laboratories or laboratory equipment (limited laboratory equipment).

$Q_{3}$ Do you design your own mixture separation laboratory activities yourself?

Continuation of Q2, as much as $40 \%$ stated that designing learning mixture separation is accompanied by laboratory activities that design their own laboratory activities and 60\% do not interfere with laboratory activities.

$Q_{4}$ Are the mixture separation laboratory activities that you apply accompanied by student worksheets

Practicing?

$50 \%$ of teacher science respondentssays that using a practice worksheet. The practice of the worksheet is not self-designed but is a modification of the internet or the result of the development of the science teacher union in his city.

From the results of the interview it can be seen that the teachers who became respondents admitted that they often carry out laboratory activities but not for the mixture separation material. The limitation of the tool is still the reason the teachers do not carry out laboratory activities of mixture separation.Teachers who carry out mixture separation laboratory activities do not design their own laboratory activities and without practical worksheets. The internet is still a source of learning designs that they design. The results of this interview will be checked with their portfolio. 


\section{Learning Document}

Based on table 3, out of 10 respondents there is no had all the 4 expectations of the benchmark tool. Majority of the respondents, these did not have any evidence related to laboratory activity in their learning document.

Table 3 Percentage result from the learning document regarding mixture separation laboratory activity

\begin{tabular}{|c|c|c|c|c|}
\hline Respondent & $\begin{array}{c}\text { Evidence of } \\
\text { laboratory } \\
\text { activity in work } \\
\text { schedule }\end{array}$ & $\begin{array}{c}\text { Evidence of } \\
\text { laboratory } \\
\text { activity in lesson } \\
\text { plan }\end{array}$ & $\begin{array}{c}\text { Evidence of } \\
\text { laboratory activity } \\
\text { in student practice } \\
\text { worksheet }\end{array}$ & $\begin{array}{c}\text { Evidence of } \\
\text { laboratory activity } \\
\text { in assessment } \\
\text { record }\end{array}$ \\
\hline 1 & $\mathrm{X}$ & $\sqrt{ }$ & $\mathrm{X}$ & $\mathrm{X}$ \\
\hline 2 & $X$ & $\sqrt{ }$ & $X$ & $X$ \\
\hline 3 & $\bar{X}$ & $X$ & $X$ & $X$ \\
\hline 4 & $X$ & $\sqrt{ }$ & $X$ & $X$ \\
\hline 5 & $X$ & $X$ & $X$ & $X$ \\
\hline 6 & $\sqrt{ }$ & $\sqrt{ }$ & $X$ & $\sqrt{ }$ \\
\hline 7 & $x$ & $\sqrt{ }$ & $\sqrt{ }$ & $x$ \\
\hline 8 & $X$ & $X$ & $X$ & $X$ \\
\hline 9 & $X$ & $X$ & $X$ & $X$ \\
\hline 10 & $X$ & $\sqrt{ }$ & $X$ & $X$ \\
\hline Acceptable (\%) & 10 & 60 & 10 & 10 \\
\hline Criteria & Very Low & Moderat & Very Low & Very Low \\
\hline
\end{tabular}

There is only one $(10 \%)$ respondent who scheduled and conducts laboratory activities, but is not equipped with a practical worksheet. this is not in accordance with the results of interviews that as many as $40 \%$ carry out mixture laboratory activities. The respondent only applied one of the mixture separation methods, that is filtration using simple paper filtering methods. While nine respondents did not carry out mixture separation laboratory activities, the reason they are because of limited facilities and infrastructure, limited teacher knowledge about mixture separation, time constraints, and according to them students were difficult to coordinate during laboratory activities.

Basic knowledge of the ten respondents who became science teachers is biology. While the separation of mixtures is included in the realm of chemical matter. Many methods of separating the mixture include filtration, sublimation, distillation, crystallization, and chromatography. According to the teacher, they have limited knowledge about the principle of the method of separating the mixture and how to use the tool. Whereas in two schools in ten respondents there was a simple distillation device, but the tool was not used because they did not understand how to use the tool.

The incompatibility of the results of interviews with learning document is also seen in the lesson plan. In fact, only $40 \%$ of interviewees admitted to designing laboratory activities while learning document were $50 \%$ has designed laboratory activities. Figure 1 shows that in the lesson plan, there are only two types of learning methods carried out by the teacher, that is leatoring method (50\%) and practice methods (50\%). Apart from the class, only one respondent carried out laboratory activities, this proved that the teachers in Lampung did not apply the existing curriculum (2013 curriculum).

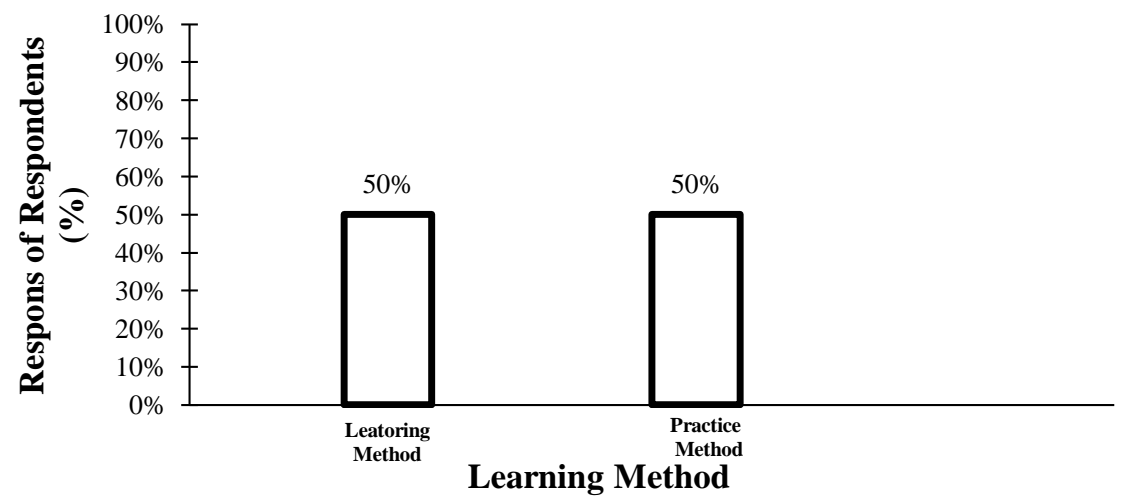

Figure 1. Graph percentage of respondent regarding mixture learning method in lesson plan

Higher order thinking skills is an important aspect in teaching and learning. Thinking skills are fundamental in educational process. A person thought can affect the ability of learning, speed and effectiveness of learning. 
Therefore, thinking skills is associated with learning process. Students who are trained to think demonstrate a positive impact on the development of their education [22].

Furthermore, only $10 \%$ with criteria very low or only one respondent which has an activity in assessment record. There are $90 \%$ of respondents reasoned that they did not make the assessment record due to lack of importance because laboratory activities were indeed not carried out. Moreover, time constraints are also the reason.The results of other studies state little knowledge and little understanding of assessment instruments by teachers cause problems [23]. Besides that contextual factors such as over-crowding of classrooms were the major obstacle to carry out assessment [24].

\section{CONCLUSION}

The results show that while teachers' perceptions regarding mixture separation in science classrooms is inadequate. Caused, there was a mismatch between teachers' perceptions, teachers' portofolio, and what was taking place in the science classroom. Important awareness of laboratory activities is quite large but is not applied in learning or learning document. In learning students are not trained in high older thinking skills.It is recommended that teacher on learning using students' practice worksheet and assessment of laboratory activity should be given attention, as most of the teachers do not record marks regularly for laboratory activity. Futhermore, laboratory activity which prepared by the teacher should arranged in lesson plan and practice schedules.

\section{ACKNOWLEDGMENTS}

This research is a graduation requirement for the master program in Universitas Lampung. Thanks to science teachers as respondents and all involved in this research.

\section{REFERENCES}

[1] Trilling, B. and Fadel C. (2009). 21st Century Skills: Learning for Life in Our Times, San Francisco: JosseyBass A Wiley Imprint

[2] Hofstein A and LunettaVN (1982). The role of the laboratory in science teaching: neglected aspects of research, Review of Educational Research, 52, 201-217.

[3] Hofstein, A and Lunetta V.N. (2004). The laboratory in science education: foundation for the 21 ${ }^{\text {stcentury, }}$ Science Education, 88, 28-54.

[4] Tobin, K.G, (1990). Research on science laboratory activities; in pursuit of better questions and answers to improve learning, School Science and Mathematics, 90, 403-418.

[5] Hodson, D. (1993). Re-thinking old ways: towards a more critical approach to practical work in school science. Studies in Science Education, 22, 85-142.

[6] Lazarowitz, R and Tamir, P. (1994). Research on using laboratory instruction in science, in D. L. Gabel. (Ed.) Handbook of research on science teaching and learning (pp. 94-130), New YorkMacmillan.

[7] Hofstein, A. (2004). The laboratory in chemistry education: thirty years of experience with developments, implementation and evaluation, Chemistry Education Research and Practice, 5,247-264.

[8] Lunetta, V.N. (1998). The school science laboratory: historical perspectives and centers for contemporary teaching, . In P. Fensham (Ed.). Developments and dilemmas in science education(pp 169-188), London, Falmer Press.

[9] Lunetta, V.N, Hofstein A, and Clough M. (2007). Learning and teaching in the school science laboratory: an analysis of research, theory, and practice, In N, Lederman. and S. Abel (Eds,), Handbook of research on science education. (pp. 393-441), Mahwah, NJ: Lawrence Erlbaum

[10] Hofstein A. and Rachel M.N. (2007). The Laboratory in science education: the state of the art. Chemistry Education Research and Practice, 2007, 8(2), 105-107

[11] Deacon, C and Hajek, A. (2010). Graduate teaching assistants' perceptions of teaching competencies required for work in undergraduate science labs. International Journal of Science Education pp 1-35

[12] Tafa, B. (2012). Laboratory activities and students practical performance: the case of practical organic chemistry. AJCE, 2(3).

[13] Toplis, R. and Allen, M. (2012). 'I do and I understand?' Practical work and laboratory use in United Kingdom schools.Eurasia Journal of Mathematics, Science \& Technology Education, 8(1), 3-9.

[14] Abrahams, I. and Millar, R. (2008). Does practical work really work? A study of the effectiveness of practical work as a teaching and learning method in school science. International Journal of Science Education, 30, 19451969 
[15] Blosser, P. (1980). A critical review of the role of the laboratory in science teaching, Columbus OH:Center for Science and Mathematics Education.

[16] Bryce T.G.K. and Robertson I.J. (1985). What can they do? A review of practical assessment in science. Studies in Science Education, 12, 1-24.

[17] Kibirige, I., Osodo, J., \& Mgiba, A. N. (2014). Exploring grade 7 science teachers' perceptions regarding practical work in Limpopo, South Africa. Mediterranean Journal of Social Sciences, 5(4), 399

[18] Harman G, Cokelez A, Dal B and Alper U. (2016) Universal Journal of Educational Research 4(1), pp 12-25

[19] Dikmenli M. (2009). Biology student teachers' ideas about purpose of laboratory work. Asia-Pacific Forum on Science Learning and Teaching, 10(2), 1-14.

[20] Fraenkel, J. R and Wallen, N. E. (2012). How to design and evalute research in education. 8th Edition. New York: The Mc Graw-Hill.

[21] Arikunto, S. 2008. Prosedur Penelitian Suatu Pendekatan Praktik. Jakarta: Rineka Karya

[22] Heong, Y. M., Othman, W. B., Yunos, J. B. M., Kiong, T. T., Hassan, R. B., \& Mohamad, M. M. B. (2011). The level of marzano higher order thinking skills among technical education students. International Journal of Social Science and Humanity, 1(2), 121

[23] Kasanda, C. D., Lubben, F., Campbell, B., Kapenda, H. M., Kandjeo-Marenga, H. U. \& Gaoseb, N. (2003). Learner-Centred Teaching - The Rhetoric and Practice the Case of Namibia, pp.134. Paper presented at the 11th SAARMSTE conference in Waterford Kamhlaba.

[24] Maboyi. T. R. \& Dekkers, P. (2003). Science teachers purpose for doing practical work - Does professional Development make a Difference? University of the North, Turfloop, South Africa. pp. 722. Paper presented at the 11th SAARMSTE conference in Waterford Kamhlaba UWC, 2003.

\section{http://www.jurnalnasionalump/index.php/dinamika}

